\title{
Zarządzanie komunikacją kryzysową w serwisie społecznościowym Facebook za pomoca public relations. Analiza wybranych sytuacji kryzysowych w latach 2011-2015
}

\begin{abstract}
Streszczenie
W artykule przedstawiono autorską typologię sytuacji kryzysouych, które podzielono na: zawinione przez organizacje i zarządzane prawidłowo, zawinione przez organizacje i zarządzane nieprawidłowo oraz niezawinione przez organizacje i zarządzane prawidłowo, a także niezawinione przez organizacje i zarządzane nieprawidłowo. Celem takiego podziału jest stuorzenie kodeksu dobrych praktyk, który będzie zawierał elementy podręcznika kryzysowego z uwzględnieniem narzędzi kryzysowych, umożliwiających uniknięcie błędów komunikacyjnych.
\end{abstract}

Słoua kluczowe: media społecznościoue, Facebook, zarządzanie kryzysoue, public relations, komunikacja.

\section{Crisis management in Facebook based on public relations. Analysis of selected crisis case studies in the years 2011-2015}

Abstract

In the article the author takes up some specific types of the crises situations in the author's division: crises committed by organization and managed correctly, crises committed by organization and managed incorrectly, crises without fault by organization and managed correctly, crises without fault by organization and managed incorrectly. The aim of this article is to prepare codex of best practices included crises tools to avoid communication mistakes.

Keywords: social media, Facebook, crisis management, public relations, communication.

\section{Wprowadzenie}

Sytuacje kryzysowe, w związku z którymi jest prowadzona komunikacja w serwisie społecznościouym Facebook, mogą mieć różną etiologię. Niektóre z nich mogą pojawić się na skutek nieprawidłowości w firmie u aspekcie jej funkcjonowania, przez co skutki takich działań dotykają w bezpośredni sposób klientów lub usługobiorców marki. Użytkownicy serwisów społecznościouych wyrażają najczęściej swoje niezadowolenie 
w serwisach społecznościouych, także na Facebooku, w postaci niepochlebnych postów lub komentarzy, często przepełnionych negatyunymi emocjami. Przykładem sytuacji kryzysowej wywołanej przez firmę może być opublikowany przez nią post niosący obraźliwy dla pewnej grupy przekaz, choć być może nie miał on takiego celu. W takich przypadkach sytuacja kryzysowa została wywołana przez markę i słusznie jest ona oskarżana przez internautów o brak profesjonalizmu.

Innym przypadkiem, w którym firma musi prowadzić komunikację kryzysową na Facebooku, mogą być sytuacje kryzysowe przez nią niezawinione. Użytkounicy seruisu społecznościouego wywołują wóuczas często sytuacje kryzysowe, pisząc niepochlebne posty i komentarze niebędące odpouviedzią na konkretne problemy firmy. Przykładem może być niezadowolenie klientóu spowodowane rozczarowaniem wynikającym z nieodpowiedniej jakości produktu lub usługi, jednak istnieje potwierdzenie tego, że były one prawidłowej jakości. Kryzys w takich przypadkach ma wyłącznie charakter medialny i nie jest związany ze złym funkcjonowaniem firmy.

Rozpatrując oba aspekty zawinionych i niezawinionych przez firmę sytuacji kryzysowych, należy przeanalizować je pod względem sprawności procedur komunikacyjnych (u tym sztabu kryzysowego) w ich rozwiązywaniu. Zarówno jedne, jak i drugie przypadki mogą być rozwiązane poprawnie przez firmę. Przy prawidłouych działaniach komunikacyjnych mogą one przechylić szalę sukcesu na stronę firmy lub mogą być przeprowadzone w sposób niepoprawny, pozostawiając problem nierozwiązany i pogrążając markę w kryzysie komunikacyjnym poprzez eskalację błędów w zakresie komunikacji z otoczeniem.

Biorąc pod uwagę uszystkie przywołane aspekty, w których może się znaleźć firma w mediach społecznościouych, należy określić typologię sytuacji kryzysouych i przeanalizować je pod względem komunikacyjnym w najpopularniejszym serwisie społecznościouym (Facebook). Cztery kategorie sytuacji są następujące: sytuacje kryzysowe zawinione przez firmę i administrowane prawidłowo, zawinione i administrowane nieprawidłowo, następnie niezawinione i administrowane prawidłowo, a wreszcie niezawinione i administrowane nieprawidłowo.

\section{Sytuacja kryzysowa zawiniona i administrowana prawidłowo}

W tego rodzaju sytuacjach kryzysowych zawinionych i administrowanych prawidłowo należy podkreślić winę firmy, która swoimi nieprzemyślanymi działaniami wywołała kryzys komunikacyjny. Jednakże dzięki swojemu profesjonalizmowi i za pomocą narzędzi, jakie daje serwis społecznościouy Facebook, potrafiła mądrze i efektywnie zarządzać kryzysem u taki sposób, że zakończył się on pomyślnie dla organizacji, nie narażając jej wizerunku na szwank. Zarazem komunikacja kryzysowa definiowana chińskim symbolem oznaczającym zaróuno „zagrożenie”, jak i „szansę”1 może

${ }^{1}$ M. Przybysz, Kościót w kryzysie? Crisis management $w$ Kościele w Polsce, Wydaunictwo Diecezji Tarnouskiej Biblos, Tarnóu 2008, s. 25. 
doprowadzić do polepszenia wizerunku i upłynięcia na jeszcze bardziej pozytywne postrzeganie firmy przez jej otoczenie. Jeśli działania zostaną podjęte profesjonalnie, odpowiedzialnie i wiarygodnie poprowadzone w oczach grup docelowych, wtedy wizerunek może ulec znacznej poprawie. Każdy konflikt, w którym marka bierze udział, można uznać za czynnik twórczy, mogący sprzyjać wyzwalaniu nowych pomysłów oraz umożliwiający wypracowywanie peunych zachowań pozbawionych schematów, a to może owocować sukcesem². Działania firmy podjęte w trakcie kampanii Heyah wykorzystującej wizerunek Lenina obrazują troskę marki o dobrą komunikację z otoczeniem i choć należą do wywołanych przez firmę bezpośrednio na Facebooku i poza nim, to działania antykryzysowe zostały jednak poprowadzone efektyunie w ramach tej samej przestrzeni serwisu, prowadząc do umocnienia wizerunku marki.

Z początkiem 2013 roku Polska Telefonia Cyfrowa (PTC), do której należała sieć komórkowa Heyah, uprowadziła kampanię marketingową wzbudzającą pytanie o granice prowokacji w reklamie. Główną postacią, do której nawiązywała komunikacja firmy, był Włodzimierz Lenin, przywódca kojarzony ze stworzeniem bolszewizmu - ustroju totalitarnego, który przerodził się w komunizm. Postać Lenina jest w krajach demokratycznych symbolem zbrodniarza i mordercy milionów rodaków. W kontekście polskim stanowi symbol wojny polsko-bolszewickiej, która również pochłonęła wiele ludzkich istnień3.

$\mathrm{Na}$ oficjalnym fanpage'u operatora od razu pojawiły się krytyczne upisy tłumaczące powód niezadowolenia internautów. Nie brakowało także głosów u obronie kampanii jako tej, która miała na celu wyśmianie komunizmu. Pojawiały się apele, żeby zdystansować się do całej sytuacji, bo to może sprawić, że w Polsce z niczego nie będzie można już żartowaćt. Po lawinowej krytyce użytkowników Facebooka firma wystosowała odpowiedź u postaci posta, mającego na celu wytłumaczenie zamysłu stworzenia takiego, a nie innego charakteru kampanii marketingowej:

W odpowiedzi na komentarze, które pojawiają się u nawiązaniu do naszej ostatniej kampanii, chcieliśmy powiedzieć, że jedynym celem reklamy jest poinformowanie Konsumentów o najnouszej ofercie sieci Heyah, której użytkounicy mogą otrzymać 60 minut do uszystkich za 1 złoty. Kampania została przygotowana w wyraźnie żartobliuy sposób i próby rozważania spotu inaczej, niż jako nawiązanie do słowa rewolucja, nie są kierunkiem, u którym chcieliśmy iść ${ }^{5}$.

Po trwającej wciąż fali krytycznych komentarzy także na Facebooku oraz zgłoszeniu do Komisji Etyki Reklamy ponad tysiąca skarg na kampanię, sieć Heyah postanouiła ją wycofać i przeprosić za reklamę z wykorzystaniem wizerunku Lenina. Kampania truała

\footnotetext{
${ }^{2}$ D. Tworzydło, Public relations - teoria i studia przypadków, Wydawnictwo Wyższej Szkoły Informatyki i Zarządzania, Rzeszów 2003, s. 44.

${ }^{3}$ A. Bialic, Niesmaczna kampania Heyah, http://komorkomania.pl/4724,niesmaczna-kampania-heyah (dostęp: 13.11.2017).

${ }^{4}$ Ł. Szewczyk, Lenin w kampanii Heyah zbyt kontrowersyjny dla internautów, http://media2. pl/reklama-pr/99420-Lenin-w-kampanii-Heyah-zbyt-kontrowersyjny-dla-internautow-wideo. html (dostęp: 13.11.2017).

${ }^{5}$ A. Bialic, op. cit.
} 
zaledwie pięć dni ${ }^{6}$. Dnia 7 stycznia 2013 roku marka wystosowała oficjalne ośuiadczenie na suoim oficjalnym fanpage’u, w którym poinformowała fanów, że pod wpływem dyskusji na temat wątków ideologicznych zdecydowała się ustrzymać kampanię.

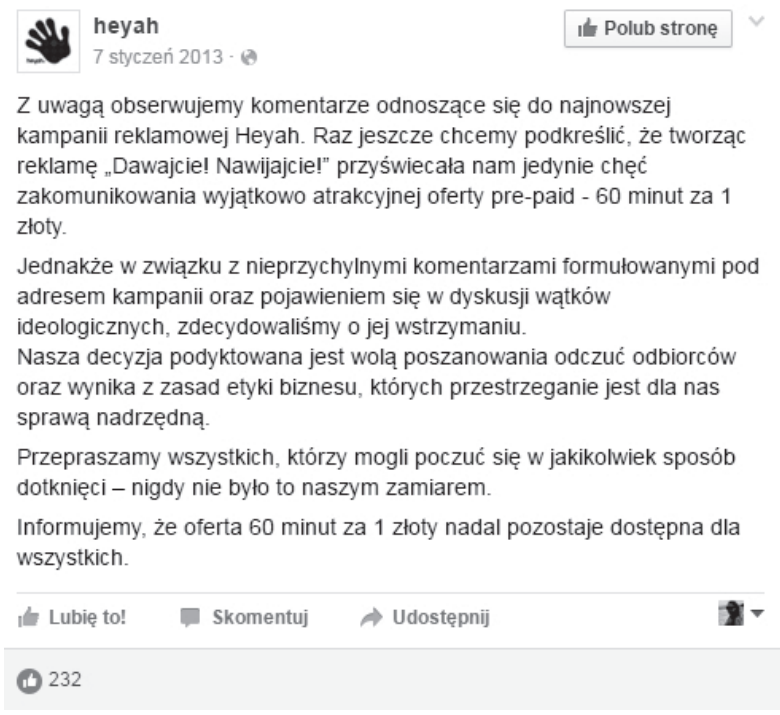

Rycina 1. Fanpage Heyah

Źródło: https://wuw.facebook.com/heyah/posts/10151265101908073 (dostęp: 16.11.2017).

Róunież pod postem, będącym oświadczeniem marki, pojauiło się ponad 500 komentarzy, w których zniecierpliwieni internauci pytali, czemu reklama wciąż nie znika z przestrzeni publicznej u postaci telewizji, radia czy outdooru. Należy zaznaczyć, że manager do spraw komunikacji Heyah nie pozostawił odbiorców samych sobie, ponieważ odpowiadał na zarzuty, tłumacząc cierpliwie, że proces zatrzymania kampanii potrua jakiś czas, ale na pewno nastąpi. Miało to pozytywny wydźwięk, ponieważ firma tym sposobem jednoznacznie podtrzymywała, że chce zrobić uszystko, by pokazać odbiorcom, jak bardzo zależy jej na opinii konsumenta.

Niektórzy użytkownicy, analizując późniejsze poczynania marki i brak jakichkolwiek zmian w wygaszaniu kampanii, stwierdzili, że konsumenci zostali oszukani przez Heyah. Takiego zdania był Przemysław Pająk, autor bloga spidersweb.pl. Swoją tezę oparł z jednej strony o własne obserwacje, że reklamy nie znikały z mediów z upływem czasu, z drugiej zaś o fachową opinię osoby z branży reklamowej. Okazało się, że reklamę z telewizji, radia oraz Internetu można uycofać w ciągu kilku godzin i nie jest to skomplikowana procedura, która zdarza się często u ostatniej chwili. Zatem reklama Heyah nie powinna być emitowana w tych wszystkich mediach zaraz po publikacji oficjalnego oświadczenia na Facebooku. Autor bloga skontaktował się także

\footnotetext{
${ }^{6}$ J. Korus, Heyah wycofuje kampanię: Lenin jest już historia, http://polska.newsweek.pl/ heyah-wycofuje-kampanie-lenin-jest-juz-historia,100236,1,1.html (dostęp: 16.11.2017).
} 
z jedną z agencji outdoorowych z zapytaniem, ile trua usunięcie reklam z billboardów, uzyskując informację, że może to potrwać od kilku dni do kilku tygodni u zależności od tego, jaki zasięg miała kampania?.

Pająk u suoim artykule pourócił do analizy słów oświadczenia, w którym napisano, że zdecydowano się na ustrzymanie kampanii, jednak nie zaznaczono, kiedy miałoby to nastąpićs ${ }^{8}$ Dlatego też nie dziwią liczne komentarze internautów zuracających uwagę na ciągłość reklam w mediach audiowizualnych.

Niezadowolenie internautów wobec działań marki wyrażało się nie tylko poprzez komentarze pod postami, lecz także w bardziej zorganizowany sposób. Stworzono wydarzenie na Facebooku, które nazwano „Stop sowietyzacji - bojkot Heyah za Lenina!”. Termin wyznaczono na 30 marca 2013 roku o godzinie 12:00. W opisie organizator przybliżył tematykę kryzysu, z którym zetknęła się sieć komórkowa, stwierdzając, że do swojej reklamy firma wykorzystała największego zbrodniarza uszechczasów, winnego śmierci ponad 100 milionów ludzi. Na wydarzeniu można było róunież dostrzec zachętę do składania skarg do Rady Reklamy z uuzględnieniem nieetycznego zachowania marki ${ }^{9}$.

Zdania internautów na oficjalnym fanpage’u marki były podzielone, ponieważ znalazły się osoby, które broniły Heyah i kontrowersyjnej kampanii, twierdząc, że młodzi ludzie będący grupą docelową sieci komórkowej nie pamiętają czasóu komunizmu i akcja reklamowa ich nie uraziła. Inne głosiły, że należy uprowadzić więcej poczucia humoru, ponieważ spot reklamowy miał charakter prześmieuczy i żartobliwy, dlatego nie należy traktować go poważnie ${ }^{10}$.

Podsumouując analizowany przypadek PTC i Heyah, można stwierdzić, że kryzys, który dotknął markę, był przez nią zawiniony, jednak w serwisie społecznościowym Facebook był administrowany poprawnie ${ }^{11}$. Wystosowano dwa oświadczenia, opublikowane nieprzypadkowo na oficjalnym fanpage'u marki, ponieważ ułaśnie na tym kanale kryzys komunikacyjny przybrał największy zasięg i wygenerował najuiększe zaangażowanie odbiorców. Pierusze z oświadczeń miało za zadanie wytłumaczyć prawidłową interpretację przekazu i wyczuć nastroje internautów. Kiedy marka Heyah upewniła się, że to nie wystarczy, zdecydowała się wycofać kampanię, kalkulując zyski i straty wynikające z nastrojów internautów. Firma zakomunikowała o tym kolejnym postem w postaci oświadczenia, jednak i pod nim pojawiło się wiele negatywnych

${ }^{7}$ P. Pająk, PTC ściemnia, że wycofało reklamy Heyah z Leninem. Oto dowody, http://www. spidersweb.pl/2013/01/ptc-sciemnia-ze-wycofalo-reklamy-heyah-z-leninem-oto-dowody.html (dostęp: 16.11.2017).

${ }^{8}$ Ibidem.

9 M. Gąsior, „Stop sowietyzacji”. Internauci chca bojkotować Heyah za reklamę z Leninem, http://natemat.pl/45769,stop-sowietyzacji-internauci-chca-bojkotowac-heyah-za-reklame-z-leninem (dostęp: 16.11.2017).

${ }^{10}$ Internauci oburzeni reklama Heyah z Leninem. „Precz z komuna”, „Podpalić ich siedziby”, http://www.wirtualnemedia.pl/artykul/internauci-oburzeni-reklama-heyah-z-leninem-precz-z-komuna-podpalac-ich-siedziby (dostęp: 16.11.2017).

${ }^{11}$ Branża: reklamy Heyah z Leninem to nic szokującego, http://wuw.wirtualnemedia.pl/ artykul/branza-reklamy-heyah-z-leninem-to-nic-szokujacego (dostęp: 16.11.2017). 
komentarzy. Tym razem chodziło o opóńnienia u znikaniu reklam z przestrzeni mediów masowych i outdoorouych. Marka, mimo szybkiego generowania nowych komentarzy, odpowiadała na poutarzające się pytania, uspokajając, że uycofywanie jest realizowane i przebiega etapowo, zapeuniając tym samym, że reklama zniknie niebawem na dobre.

Trudno stwierdzić, czy marka mówiła prawdę o wycofaniu się z nieudanego pomysłu, ponieważ kilka tygodni po oświadczeniu nadal można było obserwować plakaty na billboardach, które fotografowali i publikowali internauci. Można jednak domniemywać, że nie wynikało to z oszustwa, lecz niezbyt dobrze skoordynowanej akcji procedur odwoływania. Nie wiadomo także, czy kryzys został wywołany przypadkiem przez brak przewidzenia skutków, czy też kampania miała za zadanie zaszokować. W strategii komunikacyjnej mogło być zaplanowane wycofanie publikacji, aby stworzyć szum medialny i pokazać „ludzką twarz” marki, która słucha swojego otoczenia. Specjaliści jednak twierdzą, że kryzys z Leninem mógł jedynie zaszkodzić marce $u$ branży. Nie zaszkodził jej jednak na rynku konsumenckim.

\section{Sytuacja kryzysowa zawiniona i administrowana nieprawidłowo}

W tym punkcie zostanie przeanalizowana sytuacja, która została zawiniona przez firmę $\mathrm{w}$ ramach źle prowadzonej komunikacji z klientem lub internautą, a konsekwencją błędów był kryzys komunikacyjny na oficjalnym fanpage'u firmy. Mimo szansy administrowania go $w$ taki sposób, by w efekcie jednoznacznie zażegnać konflikt i usatysfakcjonować odbiorców, marka popełniła liczne błędy i zaniedbania. Wynikiem takiego postępowania był kryzys medialny, który przyczynił się do poinformowania o problemach firmy, także tych niezwiązanych z marką osób oraz rozszerzył zasięg kryzysu na inne kanały mediów społecznościouych, utrudniając tym samym możliwość kontrolowania kryzysu. Skutkiem działań w przypadku platformy cyfrowej nc+ był brak jednoznacznego rozwiązania sytuacji kryzysowej. Kryzys ten administrowany nieprofesjonalnie doprowadził do poważnego uszczerbku na wizerunku tej marki i pomimo upływu czasu nadal istnieje w świadomości odbiorców jako nierozwiązany.

Case study z udziałem platformy cyfrowej nc+ jest przykładem sytuacji kryzysowej zawinionej przez firmę i nieprawidłowo administrowanej. Sytuacja dotyczyła połączenia dwóch platform telewizji cyfrowej - n i Cyfry+, które weszły ponownie na rynek jako nowa marka nc+. Oficjalne ogłoszenie oferty przez prezesa nc+ nastąpiło 21 marca 2013 roku w Hilton Warsaw Hotel. Podkreślono wówczas, że od tej pory klienci nie będą musieli uybierać pomiędzy dwoma płatnymi telewizjami ${ }^{12}$.

Zaraz po ogłoszeniu nowego planu abonamentowego na oficjalnym fanpage'u nc+ wybuchł kryzys w postaci guałtownie mnożących się negatywnych komentarzy dotychczasowych abonentów platform n oraz Cyfry+ skarżących się, że zostali oszukani.

${ }_{12}$ Historia kryzysu NC+ (krok po kroku), http://www.press.pl/newsy/telewizja/pokaz/41452,Historia-kryzysu-NC_-_krok-po-kroku_(dostęp: 24.10.2017). 
Niezadowoleni klienci skarżyli się na dobór kanałów, ceny, a także na czas truania umowy. Administratorzy fanpage'a w odpowiedzi na falę krytyki wystosowali post o następującej treści:

Jest nam przykro, że nasza oferta spotkała się z taką krytyką z Waszej strony. Z drugiej strony - rozumiemy Wasze zaniepokojenie. Nie jesteśmy u stanie odpowiedzieć na każde z Waszych pytań indywidualnie. Obiecujemy, że jutro w serii postów wyjaśnimy kuestie, o które pytacie ${ }^{13}$.

Już na początku wprowadzenia nowej oferty popełniono wiele błędów komunikacyjnych. Największy problem wynikał z niepoinformowania swoich klientów w sposób rzetelny, na czym miałaby polegać zmiana i jakie niesie to następstwa dla dotychczasouego klienta. Specjaliści public relations zgodnie tuierdzili, że gdyby firma na samym początku sprawnie i wyczerpująco informowała abonentów za pomocą wiadomości e-mailowych lub kontaktów telefonicznych, w których była posiadaniu, być może do kryzysu by nie doszło. Na zapoznanie klientów ze zmianami był też czas na Facebooku, ponieważ oficjalny fanpage platformy nc+ poustał dua tygodnie przed uprowadzeniem na rynek nowej oferty. Już wtedy internauci zadawali pytania i sygnalizowali niejasności związane z nowym produktem, jednak ich głos został zignorowany przez managerów do spraw komunikacji zajmujących się administracją strony. Z takich pytań można było na bieżąco tworzyć zestaw Q\&A i zamieścić go za pomocą aplikacji notatnikowej na Facebooku bądź przypiętego na górze strony posta. Tak się nie stało, a dodatkowo materiał, jaki pojawiał się na fanpage’u firmy, sprawiał urażenie nieprzemyślanego i chaotycznego ${ }^{14}$.

Największym problemem komunikacyjnym okazały się przede wszystkim braki personalne w biurze obsługi klienta i w punktach sprzedaży. Mimo zatrudnienia dodatkowych pracouników do obsługi, liczba osób zgłaszających się z zapytaniami była większa, niż zakładała firma. Sytuacja ta sprawiła, że na fanpage’u marki oprócz krytyki dotyczącej nowej oferty zaczęły się pojawiać masowo negatywne komentarze w związku z brakiem profesjonalnej obsługi klienta i zajętych infolinii. W dniu ogłoszenia oferty na fanpage'u marki pojawiło się około czterech tysięcy komentarzy internautów, a w ciągu duóch kolejnych dni znowu około dwóch tysięcy ${ }^{15}$.

Kolejnym błędem, który jeszcze bardziej pogrążył markę w kryzysie, było stworzenie oddzielnego forum ncpluspytania.pl. W zamyśle forum miało za zadanie przekierować uszystkie negatyune komentarze $w$ jedno miejsce tak, by nie były one generowane na oficjalnym fanpage’u, który miał pełnić rolę wizytówki marki.

\footnotetext{
${ }_{13}$ M. Czaplicka, Zarzadzanie kryzysem w social media, Wydawnictwo Helion, Gliwice 2014, s. 198.

${ }_{14}$ T. Wojtas, Eksperci public relations o kryzysie nc+: strzał w stope, http://www.wirtualnemedia.pl/artykul/eksperci-public-relations-o-kryzysie-nc-strzal-w-stope (dostęp: 24.10.2017).

${ }^{15}$ M. Czaplicka, op. cit., s. 199.
} 


hct
24 marca 2013 -
Uruchomiliśmy miejsce, w którym każdy z Was będzie mógł uzyskać
odpowiedź na swoje pytania, jak i wyrazić opinię na temat oferty nc+.
Ułatwi ono nam wszystkim kontakt. Zapraszamy na
http://www.ncpluspytania.pl/.
Co ważne, aby zadać pytanie, nie trzeba się rejestrować.
Il Lubię to!
(1) Michal Sadowski i 200 innych użytkowników
23 ponowne udostẹpnienia
Pokaż wcześniejsze komentarze

Rycina 2. Fanpage nc+

Źródło: https://web.facebook.com/ncplus (dostęp: 24.03.2016).

Stworzenie zewnętrznego forum nie rozwiązało sprawy, ponieważ firma nadal ignorowała większość pytań ze strony niezadowolonych internautów, a nowe miejsce dyskusji nie przyciągnęło szerokiej rzeszy klientów. Posunięcie to nie zostało do końca przemyślane, ponieważ celem była ucieczka z kryzysem z przestrzeni Facebooka, co $w$ konsekwencji się nie udało. Forum zewnętrzne jest łatwiej kontrolować, to tu przekierouuje się częściową dyskusję z głównego strumienia komunikacji, ale za to dopuszcza anonimowość osób, nie wymagając rejestracji, co spowodowało, że firma nie mogła kontrolować, czy negatywne komentarze generują realni klienci, czy hejterzy. Poczucie anonimowości u sieci stwarza też pokusę do używania uulgaryzmów, przez co dyskusja staje się często niemerytoryczna. Wyjściem z sytuacji i pracą nad oczyszczaniem fanpage’a z krytyki mogło być stworzenie zakładki dyskusyjnej na Facebooku ${ }^{16}$.

Widząc, że największy ruch jest generowany właśnie na oficjalnym fanpage’u marki, administrator powinien od razu stać się wirtualnym biurem obsługi klienta. Mimo dużej liczby upisów generowanych w szybkim tempie manager do spraw komunikacji odpowiadający za stronę powinien przekierowywać pytania na poziom wiadomości prywatnych. Utworzony sztab, składający się z kilku lub kilkunastu osób, mógłby sprawnie odpowiadać na każde pytanie, dając poczucie klientowi, że jest on traktowany indywidualnie, a reakcja ze strony firmy jest szybka i profesjonalna. Odpowiadając na takie pytania, można było tworzyć w tym samym czasie szablony odpowiedzi, ponieważ większość pytań się poutarzała, a odpowiadanie gotouymi formułami usprawniłoby komunikację.

Po dwóch dniach trwania kryzysu i stworzonym forum dyskusyjnym administratorzy fanpage'a przestali prowadzić jakikolwiek dialog z internautami. Utworzeniu nowego miejsca u postaci forum towarzyszyło zablokowanie możliwości dodawania postów

${ }^{16}$ T. Wojtas, op. cit. 
na stronie, co jeszcze bardziej zdenerwowało użytkouników. W sposób negatywny należy także rozpatrywać wypowiedź dla portalu wirtualnemedia.pl Norberta Kilena, przedstawiciela agencji Think Kong odpowiedzialnej za administrowanie strony. Stwierdził on w wywiadzie, że należy odczekać, aż temperatura dyskusji opadnie ${ }^{17}$. Przedstawiciel agencji nie powinien się uypowiadać w mediach, ponieważ jest tylko usługodaucą firmy. Jakichkolwiek informacji mediom powinien udzielać rzecznik prasowy lub osoby zasiadające $w$ zarządzie firmy.

Platforma nc+ jako marka nie doceniła powagi sytuacji, nie posiadając przede uszystkim przygotowanego przed uprowadzeniem oferty planu postępowania u sytuacji kryzysowej, a dodatkowo nie planując na bieżąco komunikacji skierowanej u sposób bezpośredni do klientów i do mediów. Przez takie niedociągnięcia marka nie potrafiła w sprawny sposób odpowiadać na pytania i wątpliwości, które pojawiały się od samego początku uprowadzenia na rynek nowej oferty. Prowadzona w ten sposób komunikacja oceniana jest jako nieprofesjonalna, a wręcz arogancka ${ }^{18}$.

Już na samym początku, jeszcze $u$ dniu wybuchu kryzysu, internauci zauważyli, że negatywne opinie znikają usuwane lub ukrywane przez administratorów. W ramach protestu został stworzony antypage pod nazwą Anty $\mathrm{NC}+$.

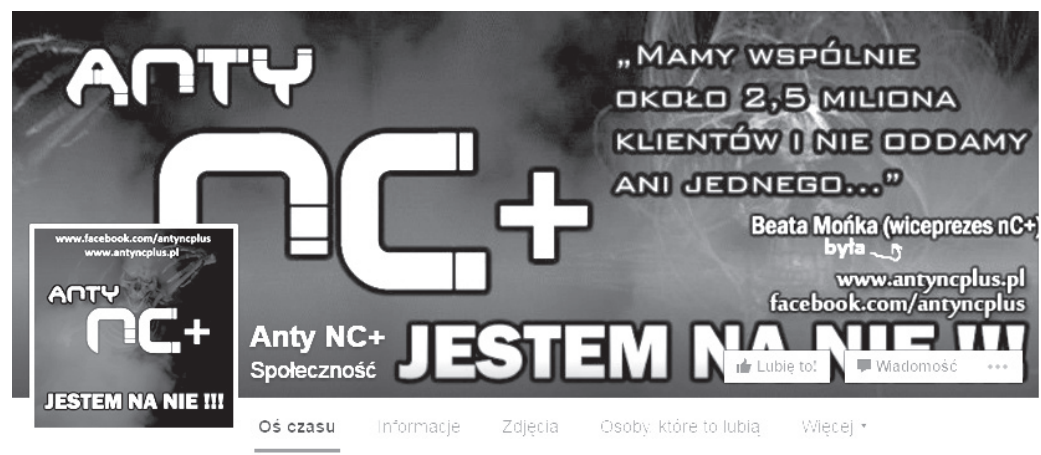

Rycina 3. Antypage Anty NC+

Źródło: https://web.facebook.com/antyncplus (dostęp: 24.10.2017).

Jego pomysłodawcą i założycielem był Dawid Zieliński, student dziennikarstwa z Poznania. Alternatyua dla oficjalnego fanpage'a miała służyć jako miejsce komunikowania się klientów bez bariery ocenzurowania. W ciągu czterech dni truania kryzysu stronę polubiło około 30 tysięcy fanów ${ }^{19}$.

\footnotetext{
${ }_{17}$ M. Fal, Internauci wściekli na nc+, a marka chowa gtowę w piasek. Czy gra na czas to dobry sposób na wizerunkowy kryzys?, http://natemat.pl/55651,internauci-wsciekli-na-nc-a-marka-chowa-glowe-w-piasek-czy-gra-na-czas-to-dobry-sposob-na-wizerunkowy-kryzys (dostęp: 24.10.2017).

${ }^{18}$ P. Luty, Czy nc+ mogto uniknać katastrofy?, http://wuw.forbes.pl/czy-nc-moglo-uniknac-katastrofy-,artykuly,146458,1,1.html (dostęp: 24.10.2017).

${ }_{19}$ Ł. Lamparski, Afera NC+: dramat w kilku aktach, http://www.conowego.pl/porady/ afera-nc-dramat-w-kilku-aktach-9040/ (dostęp: 24.10.2017).
} 


\section{Karolina Ołtarzewska}

Kiedy na początku kwietnia antypage zgromadził 80 tysięcy fanów, prezes nc+ Julien Verley wystosował pismo do założyciela Anty $N C+$, w którym zaprosił go na spotkanie. Twórca antypage’a zaproszenia do rozmouy nie przyjął, tłumacząc, że nie może być przedstawicielem wszystkich abonentów. Próba skontaktowania się prezesa nc $+\mathrm{z}$ administratorem antypage'a dobrze śuiadczy o chęci wejścia $\mathrm{w}$ dialog z niezadowolonymi klientami, wyłaniając spośród nich lidera. Jednakże spotkanie nie doszło do skutku, więc nie można do końca oceniać tego pozytywnie, gdyż efekt nie był w pełni zadowalający ${ }^{20}$. Zastanawia również fakt, że w liście do twórcy Anty NC+ była zawarta informacja o chęci porozumienia i uyjścia naprzeciu klientowi, a w dzień wysłania listu francuski prezes ogłosił, że żadnych zmian w ofercie nie będzie. Stoi to jednoznacznie u sprzeczności z celem przywołanego pisma.

Drastyczne niepowodzenia poczynań komunikacyjnych oficjalnego fanpage'a nc+ pokazuje analiza Sotrendera.

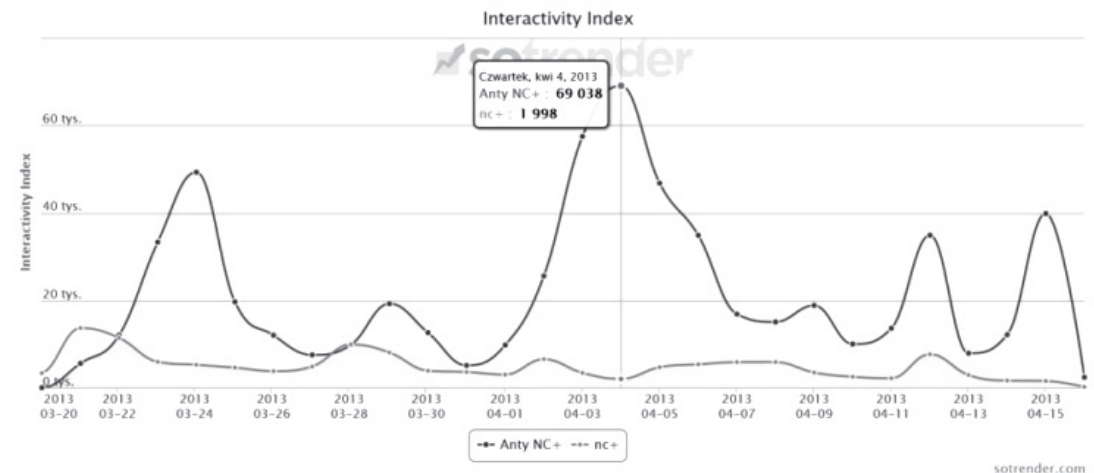

Rycina 4. Kryzys w czasach Facebooka. Raport o kryzysach PR w mediach społecznościouych Źródło: http://wuw.sotrender.com/uploads/files/kryzys-w-czasach-facebooka.pdf (dostęp: 24.03.2016).

Szczytowym momentem aktywności na antypage’u był 4 kwietnia, kiedy Urząd Ochrony Konkurencji i Konsumentów postawił właścicielom nc+ zarzuty naruszenia zbiorowych interesów konsumentów ${ }^{21}$.

Podsumouując temat kryzysu nc+ w aspekcie komunikacji na Facebooku, warto odwołać się do teorii atrybucji ${ }^{22}$. Zakłada ona, że ludzie starają się odnaleźć zuiązki przyczynowo-skutkowe odnoszące się do zachowań własnych lub innych w swoim otoczeniu. Wytłumaczenie zachodzących zjawisk musi nastąpić w sposób najprościej przysuajalny dla naszego mózgu. Można wyróżnić atrybucje weunętrzną i zewnętrzną. Pierusza z nich jest szybkim uyciąganiem uniosków, z uwzględnieniem cechy charakteru, i jest ona narażona na duży margines błędu w ocenie. Druga natomiast, oprócz cech

${ }^{20}$ M. Czaplicka, op. cit., s. 201.

${ }^{21}$ Kryzys $w$ czasach Facebooka. Raport o kryzysach PR $w$ mediach społecznościowych, http:// wuw.sotrender.com/uploads/files/kryzys-w-czasach-facebooka.pdf s. 8 (dostęp: 24.10.2017).

${ }^{22}$ F. Szymczak, Teoria atrybucji a kryzys $w$ firmie $n C+$, http://newpr.pl/wp-content/ uploads/2013/08/Teoria-atrybucji-a-kryzys-w-firmie-nC+.pdf, s. 1 (dostęp: 24.10.2017). 
charakteru, bierze róunież pod uwagę uydarzenia, jakie miały upływ na działanie jednostki.

Teoria atrybucji znalazła swoją implikację w kryzysie nc+. Biorąc pod uwagę implikację wewnętrzną, klienci uwzględniali cechy charakteru firmy, która nie odpowiadała na pytania zaniepokojonych klientów. Odebrano to jako zlekceważenie i niechęć do stworzenia uspólnego dialogu. W implikacji zewnętrznej wykorzystano kontekst podchwycony przez media i dawkowany w kolejnych przekazach, przez co kryzys uległ eskalacji. Chodziło o poprzednią fuzję Wizji TV i Canal+, która róunież charakteryzowała się nie do końca rzetelną polityką ówczesnego zarządu. Oferta w ouym czasie nie była róunież atrakcyjna, co sprawiło wrażenie, że klienci mogą być oszukani podwójnie $\mathrm{w}$ ten sam sposób. Taki proceder złożony z wewnętrznej i zewnętrznej atrybucji sprawił, że kryzys narastał ${ }^{23}$.

\section{Sytuacja kryzysowa niezawiniona i administrowana prawidłowo}

Analiza omówionego dalej case study będzie dotyczyć sytuacji, w której nie firma i jej działania były przyczyną wywołania kryzysu, ale aktywność internautów czy uspółpracouników marki. Odpowiednio poprowadzona komunikacja na Facebooku, będącym głównym serwisem prowadzenia działań public relations, sprawiła jednak, że w konsekwencji kryzys został jednoznacznie rozwiązany, a cała sprawa nie doprowadziła do poważniejszych skutków w postaci nadszarpnięcia wizerunku marki. Kampania świąteczna Empiku jest przykładem kryzysu, który został wywołany poza internetowymi działaniami marki, jednak całość kryzysu komunikacyjnego oraz prace nad jego pozytyunym rozwiązaniem zostały podjęte na Facebooku.

Sieć księgarni Empik uruchomiła w listopadzie 2014 roku bożonarodzeniową kampanię reklamową pod hasłem „Empik każdego inspiruje inaczej”. Kampania ta miała kilka odsłon i wzięły w niej udział różne osoby ze świata polskiego showbiznesu. Największą kontrowersję wzbudził jednak duet utworzony z Adama „Nergala” Darskiego i Marii Czubaszek.

Kryzys komunikacyjny tej firmy rozpoczął się właśnie na Facebooku i tam się rozwijał. We uspomnianym serwisie społecznościowym w sposób guałtouny rosła społeczność niezadowolonych klientów, definiowanych jako zwolenników prawej strony sceny politycznej oraz Kościoła ${ }^{24}$.

Adam Darski jest wokalistą heavy metalowego zespołu Behemoth, który propaguje satanizm. Maria Czubaszek była uznawana za satyryka, jednak największą dyskusję wokół swojej osoby wzbudziła, przyznając się do dokonania dwóch aborcji. Krytycznie

\footnotetext{
${ }^{23}$ Ibidem, s. 2.

${ }^{24}$ Kontrowersyjne świateczne reklamy „Empiku”. Nergal oburza katolików, http://finanse. wp.pl/kat,1033691,title,Kontrowersyjne-swiateczne-reklamy-Empiku-Nergal-oburza-katolikow,wid,17019223,wiadomosc.html (dostęp: 2.11.2017).
} 
kampanię komentowały media katolickie. Przypominały o faktach z życia obu jej bohaterów. Wartości te stały u sprzeczności z bożonarodzeniouym przekazem. Przyznanie się Adama Darskiego u jednym z programów telewizyjnych do tego, że nie cierpi okresu Bożego Narodzenia i irytuje go stworzona wokół niego otoczka i dlatego na ten czas wyjeżdża do ciepłych krajów, było przywoływane w wielu publikacjach. Marii Czubaszek zarzucano zadowolenie z zabójstwa swoich nienarodzonych dzieci ${ }^{25}$.

Empik zaraz po uybuchu kryzysu uywołanego niepochlebnymi komentarzami na swoim fanpage'u wystosował post, w którym starał się ustosunkować do zaistniałej sytuacji. Komentatorzy sytuacji kryzysowej odnosili się negatywnie do deklaracji o niezamierzonym urażeniu niektórych odbiorców, podejrzewając Empik o celowe wzbudzenie kontrowersji wokół sieci, by usłyszało o niej więcej osób ${ }^{26}$.

Zaraz po incydentach kasowania postów przez administratorów oficjalnego fanpage’a sieci sklepów utworzono antypage pod nazwą „Świątecznych zakupów nie robię w Empiku", który zdołał zgromadzić 40 tysięcy fanów. Został on jednak po niedługim czasie usunięty przez serwis społecznościouy Facebook na uniosek samego Empiku. W uzasadnieniu stwierdzono, że strona zawierała obraźliwe oraz wprowadzające w błąd informacje, naruszające dobra osobiste i prawa do znaku towarowego ${ }^{27}$. W jego miejsce utworzono kolejny „Żadnych zakupów nie robię w Empiku”, który nie zdołał już skupić tak dużej rzeszy fanów jak poprzedni ${ }^{28}$.

\begin{tabular}{l} 
empik empik.com \\
ponad rok temu \\
Przykro nam, że niektórzy bohaterowie naszej kampanii reklamowej \\
wzbudzili w Was tak negatywne emocje - co na pewno nie było \\
naszym celem. \\
Wasze opinie są dla nas bardzo ważne i na pewno weźmiemy je pod \\
uwagę, planując kolejne działania reklamowe. Prosimy jednak o \\
zachowanie poziomu dyskusji - nie godzimy się na obrażanie, \\
przekleństwa czy treści naruszające dobre obyczaje. \\
Mamy nadzieję, że znów uda nam się łączyć fanów kultury - muzyki, \\
filmu, książzek - a nie dzielić. \\
॥4 $464 \quad \rightarrow$ Share \\
\hline
\end{tabular}

Rycina 5. Fanpage empik.com w: Empikowi jest przykro, że nowa kampania wzbudza negatywne emocje, ale... nie zamierza nic z tym zrobić, 17.11.2014.

Źródło: http://www.spidersweb.pl/2014/11/empik.html (dostęp: 2.11.2017).

${ }^{25}$ M. Kozłouski, Świąteczna „kontrowersja” Empiku, http://gosc.pl/doc/2234318.Swiateczna-kontrowersja-Empiku (dostęp: 2.11.2017).

${ }^{26}$ M. Nowak, Empikowi jest przykro, że nowa kampania wzbudza negatywne emocje, ale... nie zamierza nic z tym zrobić, http://uww.spidersweb.pl/2014/11/empik.html (dostęp: 2.11.2017).

${ }^{27}$ J. Brzezicki, Czubaszek i Nergal wycofani ze świątecznej kampanii Empiku? "To zaplanowana wymiana plakatów", http://www.wirtualnemedia.pl/artykul/czubaszek-i-nergal-wycofani-ze-swiatecznej-kampanii-empiku-to-zaplanowana-wymiana-plakatow (dostęp: 2.11.2017).

${ }^{28}$ Żadnych zakupów nie robię w Empiku, https://www.facebook.com/niekupujewempiku. v2/ (dostęp: 2.11.2017). 
Rzecznik przyznał, że administratorzy z uwagą śledzą w Internecie wszystkie wątki i dyskusje - także te toczące się na antypage'u firmy, tłumacząc, że Empik nie lekceważy głosów sprzeciuu oraz stara się odpowiadać na poszczególne komentarze. Jednocześnie skrytykował autorów publikujących wyrwane z kontekstu wypowiedzi postaci z kampanii, manipulując i wprowadzając w błąd obiorców. Zauważył, że antypage nie jest nastawiony na dialog i dyskusję, ale wprowadza cenzurę, kasując przeciustawne opinie, a także blokuje ich autorów ${ }^{29}$.

Zastanawiać może fakt, że po wybuchu kryzysu, jaki pojawił się w przestrzeni fanpage'a Empiku, zaczęły znikać plakaty z Nergalem i Marią Czubaszek, a w ich miejsce zaczęły się pojauiać wizerunki piosenkarza młodzieżowego Michała Kuiatkouskiego i aktora Cezarego Pazury. Wcześniej sama rzecznik sieci Monika Marianowicz deklarowała, że opinie i uwagi internautów zostaną wzięte pod uwagę podczas przyszłych kampanii reklamouych, jednak z obecnych przedsięuzięć sieć się nie wycofa, ponieważ byłoby to przejawem cenzury. W odpowiedzi na komentarze potwierdzające wycofanie kampanii rzecznik zdementowała je w wypowiedzi do portalu wirtualnemedia.pl:

Jeszcze przed startem kampanii określiliśmy terminy ekspozycji materiałóu z udziałem poszczególnych bohaterów. Część z nich jest pokazywana z większą intensywnością (częściej i na szerszą skalę), część - w mniejszym zakresie ${ }^{30}$.

Fala niezadowolenia, która wylała się na oficjalnym fanpage’u Empiku, została uporządkowana poprzez kasowanie postów przez administratorów strony, dlatego dziś trudno dotrzeć do większości oryginalnych wpisów stworzonych przez internautów. Wiele komentarzy zawierało memy tworzone na potrzeby bojkotu sieci. Internauci przeklejali także wypowiedzi z antypage'a pod posty samego Empiku.

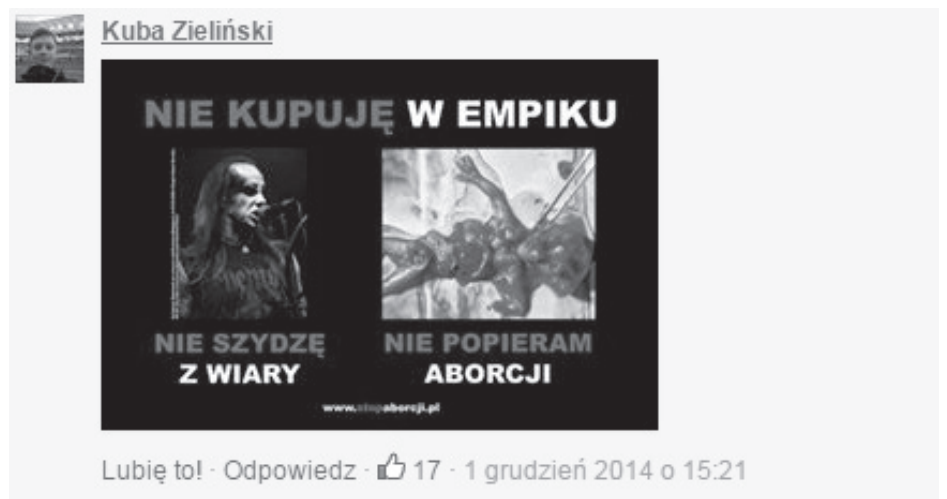

Rycina 6. Fanpage empik.com

Źródło: https://www.facebook.com/empikcom (dostęp: 2.11.2017).

${ }^{29}$ P. Rybicki, Empik odpowiada oburzonym klientom: Nie wycofamy Nergala z reklamy, http://finanse.wp.pl/kat,1033691,title,Empik-odpowiada-oburzonym-klientom-Nie-wycofamy-Nergala-z-reklamy,wid,17038397, wiadomosc.html?ticaid=113d20 (dostęp: 2.11.2017).

${ }^{30}$ Ibidem. 


\section{Karolina Ołtarzewska}

Tuż przed Bożym Narodzeniem na fanpage'u Empiku pojawił się post podpisany przez prezesa sieci sklepów Olafa Szymanouskiego, w którym życzył on radosnych świąt. Podziękował tym, którzy dokonali świątecznego zakupu w salonach, tych zaś, których kampania reklamowa uraziła, przeprosił i potwierdził, że nie było to celowe i nie miało na celu prowokacji ${ }^{31}$.

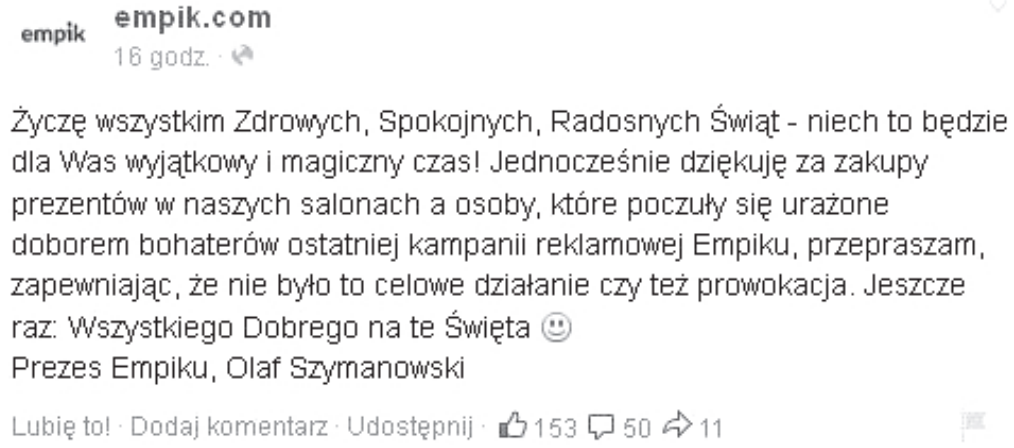

Rycina 7. Fanpage empik.com w: Lepiej późno niż wcale - Empik przeprasza za dobór bohaterów światecznej kampanii, 24.12.2014

Źródło: http://niezalezna.pl/62653-lepiej-pozno-niz-wcale-empik-przeprasza-za-dobor-bohaterow-swiatecznej-kampanii (dostęp: 2.11.2017).

Zdaniem ekspertów autorzy strategii, tworząc ją, musieli wziąć pod uwagę, że udział w kampanii dwojga kontrowersyjnych osób może wywołać kryzys w mediach społecznościowych, w przestrzeni których najpopularniejszym kanałem jest Facebook.

Taką diagnozę mogą potwierdzać uyniki badań Instytutu Monitorowania Mediów, które uskazują, że od początku kampanii, czyli 5 listopada, do 18 dnia tego samego miesiąca w całej przestrzeni internetowej oraz mediów społecznościowych ukazało się 912 publikacji na temat sieci Empik. Zawierały one zarówno przekazy pozytywne, jak i negatywne ${ }^{32}$.

Strategia oraz kreacja świątecznej kampanii została przygotowana przez agencję Change Integrated, za produkcję zaś spotów był odpouiedzialny dom mediouy Play Production, planowaniem i zakupem mediów zajął się dom mediouy Lowe Media ${ }^{33}$. W tym aspekcie należy jednak negatyunie interpretować wydawanie komunikatu prasowego do mediów usługodawcy Empiku, czyli przedstawiciela agencji public relations obsługującej uprowadzanie strategii kampanii reklamowej.

\footnotetext{
${ }^{31}$ Lepiej późno niż wcale - Empik przeprasza za dobór bohaterów światecznej kampanii, http://niezalezna.pl/62653-lepiej-pozno-niz-wcale-empik-przeprasza-za-dobor-bohaterow-suiatecznej-kampanii (dostęp: 2.11.2017).

${ }^{32}$ D. Różańska, A. Małuch, Nergal i Czubaszek w bożonarodzeniowej kampanii Empiku to nie byt przypadek, http://wuw.press.pl/newsy/reklama/pokaz/47187,Nergal-i-Czubaszek-w-bozonarodzeniouej-kampanii-Empiku-to-nie-byl-przypadek (dostęp: 2.11.2017).

33 Ł. Brzezicki, op. cit.
} 
Podsumouując antykryzysowe działania Empiku na Facebooku, należy stwierdzić, że konsekwencją swojego działania firma poradziła sobie z kryzysem, ponieważ nie wywołał on znaczącego uszczerbku na wizerunku oraz sprzedaży produktów. Antypage stuorzony przez przeciwników kampanii miał około 40 tysięcy fanóu przed jego usunięciem. Nie był zbyt dużym zagrożeniem u porównaniu do ponad półmilionowej społeczności oficjalnego fanpage’a sieci sklepów. Decyzja o zgłoszeniu Facebookowi skargi na antypage przez część ekspertów została źle oceniona. Nie przyniosła ona negatyunego skutku dla firmy. Wpraudzie poustał kolejny pod podobną nazuą, ale nie zdołał już przyciągnąć do siebie kilkudziesięciotysięcznej liczby fanów. Słusznym argumentem we wniosku do Facebooka ze strony Empiku było nieuzasadnione używanie zastrzeżonego logotypu firmy oraz oczernianie i naruszanie dobrego imienia marki za pośrednictuem uulgaryzmów. Nie było także sensu wchodzenia w dialog z osobami skupionymi wokół antystrony, ponieważ większość komentarzy była niemerytoryczna. Pozornym błędem z perspektywy działań mogło być kasowanie komentarzy niezadowolonych z kampanii internautów. Jeśli treści pisane przez użytkowników Facebooka uchodzą za powszechnie obelżywe i wulgarne, wówczas rolą administratora jest utrzymywanie poziomu kultury wypowiedzi i ich moderacja. Uczyniono to $w$ jednym z postów, apelując o dobieranie odpowiednich słów przy krytyce sklepu.

Mimo wielu poprawnych działań marka popełniła jednak kilka błędów. Pieruszym stało się pozwolenie na uypowiadanie się do mediów swojego usługodawcy, jakim był przedstawiciel agencji PR obsługującej komunikację podczas kampanii. W mediach powinien się wypowiadać tylko rzecznik prasouy sieci lub osoba zasiadająca w zarządzie. Kolejnym błędem było usunięcie uszystkich swoich postów wygenerowanych w czasie kryzysu. Nie ma obecnie po nich śladu na oficjalnym fanpage'u. Wynika to zapewne z chęci całkowitego zatarcia śladów po problemie, który truał kilka miesięcy. Nie było to jednak potrzebne, ponieważ sprawia to wrażenie chęci ukrywania faktów, co nie jest zausze przychylnie postrzegane. Screeny z postów są dostępne w Internecie, w innych przestrzeniach niż Facebook.

Kryzys ten nie był wywołany przez samą markę niezależnie od tego, jaka była motywacja kampanii i strategia marketingowa. Kryzys wywołali internauci serwisu społecznościowego Facebook. Większość działań w komunikacji kryzysowej została wykonana poprawnie, zgodnie z zasadami panującymi w mediach społecznościouych i z punktu widzenia ochrony wizerunku firmy. Zarządzanie komunikacją kryzysową w tym kontekście należy zaliczyć do prawidłowo poprowadzonych.

\section{Sytuacja kryzysowa niezawiniona i administrowana nieprawidłowo}

Ostatnim spośród zaprezentowanej typologii sytuacji kryzysouych jest podział na kryzys niezawiniony i administrowany nieprawidłowo. Prezentuje on przypadek, w którym działania marki same w sobie nie były kryzysogenne, ale środowisko zewnętrzne 
przyczyniło się do wywołania kryzysu komunikacyjnego marki. Kryzys sieci komórkowej Orange jest przykładem, który swój początek i przebieg miał jedynie u sferze niebieskiego serwisu i poustał za przyczyną nieprzemyślanego w skutkach wpisu managera do spraw komunikacji.

Klasyczny przykład posta zamieszczonego przez pracowników firmy Orange na jej oficjalnym fanpage'u jest często przywoływany. Wina za jego poustanie nie leży po stronie marki, ponieważ nie wiąże się z błędem komunikacyjnym samej firmy bądź konkretnym defektem zuiązanym z jej produktem lub usługą.

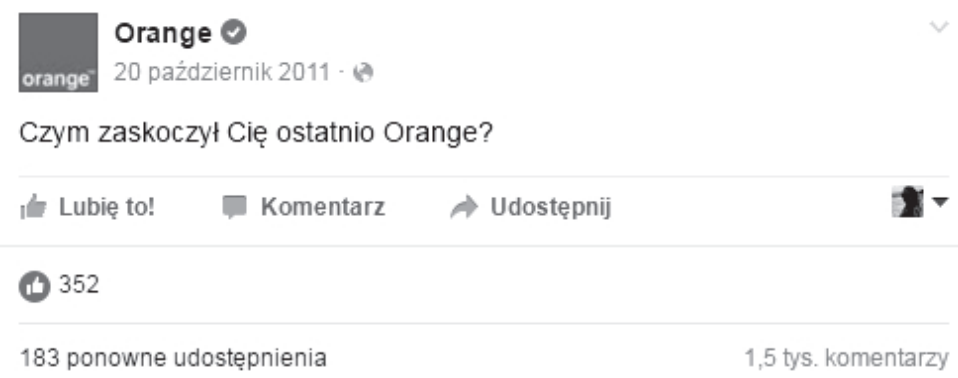

Rycina 8. Fanpage Orange

Źródło: https://www.facebook.com/orangepolska/posts/289160797770158 (dostęp: 3.11.2017).

Przyczyną kryzysu było opublikowanie przez administratora fanpage’a posta o treści „Czym zaskoczył Cię ostatnio Orange?”, który lawinowo wywołał niepochlebne komentarze dotyczące usług firmy. Post miał być komunikatem, pod którym będzie można pochualić markę za jej starania i profesjonalizm. Jednakże źle sformułouane pytanie nawiązywało do szerszego kontekstu i zachęcało przede wszystkim do wydania niepochlebnej opinii klientów posiadających złe doświadczenia z usługodawcą. Statusy w mediach społecznościowych pisane $w$ takim tonie pasują przede uszystkim do marek produktów szybko zbywalnych, ponieważ o wiele trudniej je skrytykować. Inaczej jest z usługami, które ze względu na suoją wieloaspektowość dają więcej możliwości do niepochlebnych opinii ${ }^{34}$.

Monika Kaczmarek-Śliwińska wymienia cechy, które są silnie związane z poustawaniem kryzysu organizacji ${ }^{35}$.

- zuiązany pośrednio z obecnością w mediach społecznościowych;

- zuiązany bezpośrednio z obecnością w mediach społecznościouych;

- zuiązany wyłącznie z przestrzenią offline.

Kryzys komunikacyjny Orange należy zaliczyć do tego, który u sposób bezpośredni wiąże się z obecnością u serwisie społecznościouym Facebook, ponieważ tam miał suój początek, w tej przestrzeni się rozwijał, a następnie wygasł nierozwiązany jednoznacznie

34 J. Prószyński, Social kryzys, https://pijarukoksu.wordpress.com/2011/10/27/social-kryzys/ (dostęp: 3.11.2017).

${ }^{35}$ M. Kaczmarek-Śliwińska, Public relations $w$ przestrzeni mediów społecznościowych działania organizacji i jej pracowników, Politechnika Koszalińska, Koszalin 2013, s. 150. 
przez firmę. Statystyki Sotrendera uskazują, że 20\% z prawie 1300 opublikowanych komentarzy przybyło w ciągu 16 minut od wstawienia statusu. Tematem niepochlebnych opinii były przede wszystkim wysokie rachunki, nieatrakcyjna oferta czy niezgodna z oczekiwaniami jakość usług. Komentarze stały się samonapędzającą „kulą śnieżną”. Około dwie trzecie uczestników dyskusji wypowiedziało się na oficjalnym fanpage'u Orange po raz pieruszy, a większość internautów napisała tylko jeden komentarz ${ }^{36}$.

Analizując ten kryzys komunikacyjny, należy jako zaletę rozpatrywać późniejszy post wystosowany przez administratora, w którym marka dziękuje za komentarze i wykazuje wolę poprawy usług.

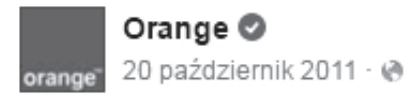

Drodzy, dziękujemy za wszystkie Wasze odpowiedzi. Wszystkie są dla nas istotne i dokładnie je przeanalizujemy. Pytanie zadaliśmy w celach badawczych - Wasza opinia jest dla nas ważna. Będziemy dokładać starań, żeby zaskakiwać Was pozytywnie.

\section{Lubiẹ to! $\quad$ Komentarz $\Rightarrow$ Udostẹpnij}

Rycina 9. Fanpage Orange

Źródło: https://www.facebook.com/orangepolska/posts/289256077760630?comment_id=4239820\& offset $=0 \&$ t otal_comments=162 (dostęp: 3.11.2017).

Była to zbyt późna reakcja na kryzys, ponieważ pojawił się on dopiero sześć godzin po publikacji kryzysogennego statusu. Szybka odpowiedź na pierusze komentarze mogła doprowadzić do zakończenia sytuacji. Administrator mógł szybko przyznać się do błędu w postaci nieprecyzyjnego pytania i zadać go raz jeszcze w odpowiednim brzmieniu ${ }^{37}$ lub humorystycznie odpowiedzieć na pierwsze pojawiające się komentarze, gratulując poczucia humoru followersom.

Odmiennym wyjściem z sytuacji mogło być szybkie skierowanie rozmowy na inny temat. Zabrakło zapewne także komunikacji prywatnej z internautami, przynajmniej z tymi najbardziej aktywnymi na wallu, co może świadczyć o braku strategii kryzysowej, która pomogłaby działać według określonych reguł ${ }^{38}$.

Podsumouując, kryzys komunikacyjny marki Orange jest przykładem, jak nie należy postępouać u przestrzeni Facebooka oraz szeroko pojętych medióu społecznościouych. Nie można uznać, że kryzys wywołała marka, ponieważ zadała źle sformułowane pytanie, na które internauci nie pozostali obojętni. Każdy kryzys można rozuiązać

\footnotetext{
${ }^{36}$ M. Czaplicka, op. cit., s. 148.

${ }^{37}$ M. Kowalczys, Orange strzela sobie w kolano - niefortunne pytanie może wiele kosztować, http://przerwanareklame.pl/artykuly/orange-strzela-sobie-w-kolano-niefortunne-pytanie-moze-wiele-kosztowac/ (dostęp: 3.11.2017).

${ }^{38}$ M. Czaplicka, op. cit., s. 151.
} 
ze skutkiem pozytywnym dla marki, czego administratorom fanpage'a Orange nie udało się zrobić, pozostawiając kryzys nierozwiązanym.

\section{Podsumowanie}

Artykuł poświęcony kryzysom komunikacyjnym w serwisie społecznościouym Facebook miał za zadanie kategoryzację konkretnych przypadków poprzez sklasyfikowanie ich w cztery grupy. Pierusza dotyczyła kryzysu zawinionego i administrowanego poprawnie przez markę, która sprawnie działała w sieci. Druga grupa objęła kryzys zawiniony, ale przeprowadzony nieprawidłowo, co mogło wynikać z braku doświadczenia lub profesjonalizmu. Trzecia grupa to kryzys z winy marki popraunie administrowany, ostatnia zaś dotyczyła kryzysu niezawinionego, ale mimo to administrowanego nieodpowiednio z punktu widzenia komunikacyjnego. Wszystkie wymienione grupy wyłonione w klasyfikacji zostały poparte analizą konkretnych przypadków.

\section{Bibliografia}

Bialic A., Niesmaczna kampania Heyah, http://komorkomania.pl/4724,niesmaczna-kampania-heyah (dostęp: 13.11.2017).

Branża: reklamy Heyah z Leninem to nic szokującego, http://www.wirtualnemedia.pl/artykul/ branza-reklamy-heyah-z-leninem-to-nic-szokujacego (dostęp: 16.11.2017).

Brzezicki Ł., Czubaszek i Nergal wycofani ze świątecznej kampanii Empiku? „To zaplanowana wymiana plakatów", http://www.wirtualnemedia.pl/artykul/czubaszek-i-nergal-wycofani-ze-swiatecznej-kampanii-empiku-to-zaplanowana-wymiana-plakatou (dostęp: 2.11.2017).

Czaplicka M., Zarzadzanie kryzysem w social media, Wydawnictwo Helion, Gliwice 2014.

Fal M., Internauci wściekli na nc+, a marka chowa głowę w piasek. Czy gra na czas to dobry sposób na wizerunkowy kryzys?, http://natemat.pl/55651, internauci-wsciekli-na-nc-a-marka-chowa-glowe-w-piasek-czy-gra-na-czas-to-dobry-sposob-na-wizerunkowy-kryzys (dostęp: 24.10.2017).

Gąsior M., „Stop sowietyzacji”. Internauci chcą bojkotować Heyah za reklamę z Leninem, http:// natemat.pl/45769,stop-sowietyzacji-internauci-chca-bojkotowac-heyah-za-reklame-z-leninem.

Historia kryzysu NC+ (krok po kroku), http://www.press.pl/newsy/telewizja/pokaz/41452,Historia-kryzysu-NC_-_krok-po-kroku_(dostęp: 24.10.2017).

Internauci oburzeni reklama Heyah z Leninem. „Precz z komuna”, „Podpalić ich siedziby”, http://wuw.wirtualnemedia.pl/artykul/internauci-oburzeni-reklama-heyah-z-leninem-precz-z-komuna-podpalac-ich-siedziby (dostęp: 16.11.2017).

Kaczmarek-Śliwińska M., Public relations $w$ przestrzeni mediów spolecznościowych - dziatania organizacji i jej pracowników, Politechnika Koszalińska, Koszalin 2013.

Kontrowersyjne świąteczne reklamy „Empiku”. Nergal oburza katolików, http://finanse. wp.pl/kat,1033691,title,Kontrowersyjne-swiateczne-reklamy-Empiku-Nergal-oburza-katolikow,wid,17019223,wiadomosc.html (dostęp: 2.11.2017).

Korus J., Heyah wycofuje kampanię: Lenin jest już historia, http://polska.newsweek.pl/ heyah-wycofuje-kampanie-lenin-jest-juz-historia,100236,1,1.html (dostęp: 16.11.2017). 
Kowalczys M., Orange strzela sobie w kolano - niefortunne pytanie może wiele kosztować, http://przerwanareklame.pl/artykuly/orange-strzela-sobie-w-kolano-niefortunne-pytanie-moze-wiele-kosztowac/ (dostęp: 3.11.2017).

Kozłouski M., Świąteczna „kontrowersja” Empiku, http://gosc.pl/doc/2234318.Swiateczna-kontrowersja-Empiku (dostęp: 2.11.2017).

Kryzys w czasach Facebooka. Raport o kryzysach PR w mediach spotecznościowych, http:// wuw.sotrender.com/uploads/files/kryzys-w-czasach-facebooka.pdf (dostęp: 2.11.2017).

Lamparski Ł., Afera NC+: dramat w kilku aktach, http://www.conowego.pl/porady/afera-nc-dramat-w-kilku-aktach-9040/ (dostęp: 24.10.2017).

Lepiej późno niż wcale - Empik przeprasza za dobór bohaterów świątecznej kampanii, http://niezalezna.pl/62653-lepiej-pozno-niz-wcale-empik-przeprasza-za-dobor-bohaterow-suiatecznej-kampanii (dostęp: 2.11.2017).

Luty P., Czy nc+ mogło uniknąć katastrofy?, http://www.forbes.pl/czy-nc-moglo-uniknac-katastrofy-,artykuly,146458,1,1.html (dostęp: 24.10.2017).

Nowak M., Empikowi jest przykro, że nowa kampania wzbudza negatywne emocje, ale... nie zamierza nic z tym zrobić, http://www.spidersweb.pl/2014/11/empik.html (dostęp: 2.11.2017).

Pająk P., PTC ściemnia, że wycofało reklamy Heyah z Leninem. Oto dowody, http://www. spidersweb.pl/2013/01/ptc-sciemnia-ze-wycofalo-reklamy-heyah-z-leninem-oto-dowody. html (dostęp: 2.11.2017).

Prószyński J., Social kryzys, https://pijarukoksu.wordpress.com/2011/10/27/social-kryzys/ (dostęp: 3.11.2017).

Przybysz M., Kościół w kryzysie? Crisis management $w$ Kościele w Polsce, Wydawnictuo Diecezji Tarnouskiej Biblos, Tarnów 2008.

Różańska D., Małuch A., Nergal i Czybaszek w bożonarodzeniowej kampanii Empiku to nie byt przypadek, http://wuw.press.pl/newsy/reklama/pokaz/47187,Nergal-i-Czubaszek-w-bozonarodzeniowej-kampanii-Empiku-to-nie-byl-przypadek (dostęp: 2.11.2017).

Rybicki P., Empik odpowiada oburzonym klientom: Nie wycofamy Nergala z reklamy, http:// finanse.wp.pl/kat,1033691,title,Empik-odpowiada-oburzonym-klientom-Nie-wycofamy-Nergala-z-reklamy,wid,17038397,wiadomosc.html?ticaid=113d20 (dostęp: 2.11.2017).

Szewczyk Ł., Lenin w kampanii Heyah zbyt kontrowersyjny dla internautów, http://media2. pl/reklama-pr/99420-Lenin-w-kampanii-Heyah-zbyt-kontrowersyjny-dla-internautow-wideo. html (dostęp: 2.11.2017).

Szymczak F., Teoria atrybucji a kryzys $w$ firmie $n C+$, http://newpr.pl/wp-content/ uploads/2013/08/Teoria-atrybucji-a-kryzys-w-firmie-nC+.pdf (dostęp: 24.10.2017).

Tworzydło D., Public relations - teoria i studia przypadków, Wydaunictwo Wyższej Szkoły Informatyki i Zarządzania, Rzeszów 2003.

Wojtas T., Eksperci public relations o kryzysie nc+: strzat $w$ stope, http://www.wirtualnemedia. $\mathrm{pl} /$ artykul/eksperci-public-relations-o-kryzysie-nc-strzal-w-stope (dostęp: 24.10.2017).

Żadnych zakupów nie robię w Empiku, https://www.facebook.com/niekupujewempiku.v2/ (dostęp: 2.11.2017). 